\title{
MARKETING RESEARCH PROSPECTS FOR THE DEVELOPMENT OF UNMANNED VEHICLES IN UKRAINE
}

The article is devoted to the features of the introduction of unmanned transport in Ukraine. The problems that arise in the process of innovation development are considered. The survey revealed the attitude of consumers to the emergence of unmanned vehicles. On the basis of the study recommendations for the effective implementation of unmanned vehicles are formed.

Keywords: marketing research, unmanned transport, innovative transport

\section{DOI: 10.15276/mdt.2.4.2018.7}

Statement of the problem in general form and it's connection with important scientific or practical tasks. With each passing day, the near and so distinctly visible robotic future is approaching us. Already today we can observe the birth of new, bright ideas and technologies. One of the most interesting, promising and popular technologies is the idea of creating unmanned vehicles. The urgency of the chosen problem is connected with the rapidly growing number of developments in the field of unmanned control, including the advent of the Ukrainian development of an unmanned module. The purpose of the study was to identify possible problems of the emergence of unmanned vehicles in Ukraine from potential consumers and to develop recommendations for improving the attitude of society to innovation. Creating a full-fledged unmanned vehicle - one of the most exciting challenges for the technological thought of the beginning of the XXI century for companies around the world.

Analysis of the latest research and publications, which initiated the solution of this problem and on which the author relies. Research in the field of unmanned vehicles involved the leading international consulting company Json \& Partners, the results of which was compiled forecast of sales of autonomous vehicles in the world. According to the study, the market for sales of self-managed cars will grow from 330 thousand cars in 2017 to 30.4 million cars per year by 2035 . The main growth will be gained by the market starting in 2025 , when major automakers, and especially Chinese, will start to launch autonomous cars of class 3 en masse.

(C) 2018 The Authors. This is an open access article under the CC BY license (http://creativecommons.org/licenses/by/4.0/) 
Also, research in this area was carried out by an international network of companies offering professional consulting and auditing services - PricewaterhouseCoopers (PwC). According to analysts PwC, the first unmanned vehicles should appear on the roads in 2021 . However, they will require some driver intervention in certain situations. A complete transition of vehicles to the highest level of autonomy will occur in another 10 years.

Highlighting the previously unresolved parts of the general problem to which the article is devoted. The study revealed the readiness of the population to the emergence of autonomous transport in Ukraine and the main problems hindering the introduction of innovation.

Formulation of the purpose of the article (statement of the problem). The purpose of the study is to identify possible problems of the emergence of unmanned vehicles in Ukraine from potential consumers and to develop recommendations for improving society's attitude towards innovation.

Based on the purpose of the work, we have compiled the main objectives of the study:

- To investigate the state of the world and Ukrainian unmanned vehicle market.

- To determine the level of public confidence in autonomous transport.

- To identify the main problems and prospects for the implementation of innovation.

- To determine what criteria affect the attitude to innovation.

- Investigate the attitude of the population towards Ukrainian developments.

- To make recommendations regarding the changes that are necessary for the introduction of technology in Ukraine.

Statement of the main material of the research with full justification of the scientific results obtained.

To accommodate the full range of possibilities, SAE (Automotive Engineers' Community) has developed a system for classifying automobile automation [4]. It consists of 6 levels, starting with zero, where the driver completely controls the process of movement, and ending with the fifth, where the car does everything himself in any circumstances:

Level 0: lack of control over the machine, but there may be a notification system

Level 1: the driver must be ready to take control at any time. The following automated systems may be present: cruise control (ACC, Adaptive Cruise Control), automatic parking system, and lane Keeping Assistance warning system (LKA, Type 2).

Level 2: the driver must respond if the system could not cope on its own. The system controls acceleration, braking and taxiing. The system may be disabled.

Level 3: the driver may not control the car on roads with "predictable" traffic (for example, autobahns), but be ready to take control.

4th level: similar to the 3rd level, but no longer requires the attention of the driver.

Level 5: the person does not require any action other than starting the system and specifying the destination. An automated system can reach any destination, unless otherwise prohibited by law.

Despite the childish age of the UAV market, it is already possible to carry out segmentation on it. There are four main groups.

1. Financial and marketing players. They sell "show." The statements of the developers of this group are significantly ahead of the real state of affairs. Among them are Google, Tesla, Apple. Companies in this group can also be called optimists. They come to an unusual market for themselves, having neither the practice of selling cars, nor a deep understanding of its features, and are trying to form new rules. Therefore, it is a group of companies rather risk-averse.

2. Practice companies. These are well-known automakers (Mercedes, Renault-Nissan and others), developers of Tier-1, Tier-2 components (Valeo, Bosch, ZF TRW, Continental) 
and other companies that are already actively selling ready-made solutions in print runs that count seven or even eight. zeros. The goal of this group of players is to create the safest possible solution. The speed of implementation of the product for them is secondary. They declare only the real functions of their systems, understanding all their responsibility for security.

3. Service Providers. These are commercial fleets of vehicles or fleets (taxis, cargo carriers, logistics, etc.), as well as all sorts of social services (disabled people, etc.). Among them - Uber, Lyft, Sidecar and others. A distinctive feature of the companies in this group is specialization in a fairly narrow and does not require serious software mathematics in combination with already existing hardware devices.

4. Suppliers of individual solutions for unmanned vehicles. It can be either a boxed product (Mobileye offers such solutions), or hardware solutions, or complex intellectual complexes. The Intel and Mobileye deal confirms the strong position of this group [5].

Geographically, the market is segmented in North America, Europe, Asia Pacific and the rest of the world.

Currently, many companies are developing their products for the mainstream market, including General Motors, Volkswagen, Audi, BMW, Volvo, Nissan, Google, Cognitive Technologies and others.

These developments include Google autonomous cars, MIG robots (Made in Germany), AKTIV, VisLab car from Braunschweig, named Leonie, as well as the project of KAMAZ PJSC and Cognitive Technologies to create an unmanned vehicle by 2025 [6].

One of the most advanced companies in the field of autopilot can be called Tesla (USA). She already sells electric cars Model S and Model X with such a function. During the trip, the system recognizes hundreds of elements: road markings and signs, traffic lights, pedestrians and other cars, and even background blurred while driving.

In 2016, in Zaporizhia showed the first domestic autopilot Lanos. The development of the autopilot module Pilot Drive engaged Zaporozhye company Infocom Ltd. According to the developers, the autopilot recognizes the road markings, its width and is able to navigate off-road conditions. In particular, auto sensors cover 360 degrees, which eliminates the occurrence of blind spots.

In addition, in the drone installed sensory systems that are protected from rain and fog, which recognize road signs, pedestrians and even animals that can run onto the road. As they say in Infocom, the car's reaction to an obstacle is instantaneous - the analysis and decisionmaking system works in a fraction of seconds.

With its decision, Infocom plans to enter the international market. However, first of all, the company seeks to develop unmanned infrastructure in Ukraine and is preparing to come up with a proposal to the government to assist in the development of unmanned technologies in the country. Actually, for the development of this very infrastructure in Infocom they came up with the concept of smart roads or Smart Roads. Her vocation is to contribute to improving the safety of movement of autopilot vehicles and the development of road infrastructure in general.

To solve the research problems, a questionnaire was developed:

Questionnaire "Marketing research of the prospects of unmanned vehicle operation in Ukraine"

1. Do you have a driver's license?

- Yes

- Not 
2. Do you know the technology of unmanned auto control?

- Yes

- Not

3. Will you feel safe driving an unmanned vehicle?

- Absolutely not safe

- Not safe

- Difficult to answer

- Safe

- Totally safe

4. What attracts you most in an unmanned vehicle?

- Security

- Ability to do another thing

- Other

5. What scares you the most in unmanned cars?

- Possibility of technical failure in work

- Impossibility to influence the situation

- The possibility of hacker hacking

6. If you had a chance today to use an unmanned car, what would you do?

- Would definitely try. Everything new is interesting to me

- Rather, yes. New a little alarming, but the interest is stronger.

- Difficult to answer

- Probably not. There is uncertainty that the technology has not yet been tested to the end.

- Definitely not. In the drone sit only suicide

7. Do you think that autonomous cars will be useful to society?

- Yes

- Not

8. Do you think that with the advent of unmanned vehicles the number of accidents will decrease?

- Yes

$-\mathrm{Not}$

9. Are you familiar with the Ukrainian development - Pilotdrive autopilot module?

- Yes

- Not

10. Do you believe that Ukraine will be able to become one of the leaders in the world market for unmanned technology?

- Yes

- Not

11. What can you call the main problem in the implementation of unmanned control technology in Ukraine?

12. Age

$-18-25$

$-25-30$

$-30-40$

$-40-50$

- more than 50

13. Gender

- Female

- Male 
To obtain a representative sample and $95 \%$ accuracy of the results, it would be advisable to interview at least 400 respondents selected from the database using special software. For the lack of such an opportunity, 43 respondents selected by the researcher were interviewed. Therefore, the resulting sample is non-representative and deterministic. Its volume is 43 respondents. The survey was conducted on the Internet through Google form.

To perform the first task, an analysis of Internet sources and the work of modern researchers was carried out.

To solve the second task, the respondents were asked a set of questions $(3,4,6,7,8)$.

To reveal the solution of the third problem, questions 5, 11 were asked.

To identify the relationship between age and attitudes towards innovation, question number 12 was added.

To study the attitude of the population to the Ukrainian development questions 11, 10, 9 were asked.

Processing of survey data was carried out using software such as IBM SPSS Statistics 21 and Google forms. Consider each question separately.

Question 1. Do you have a driver's license?

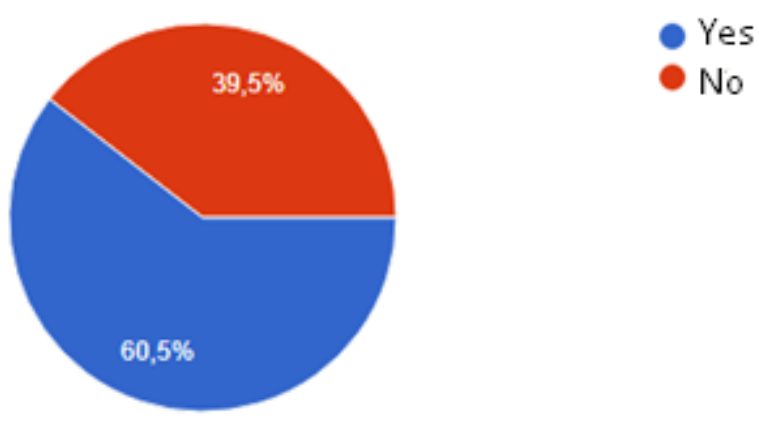

Based on the chart, we see that the majority of respondents have a driver's license.

Question 2. Familiarity with technology

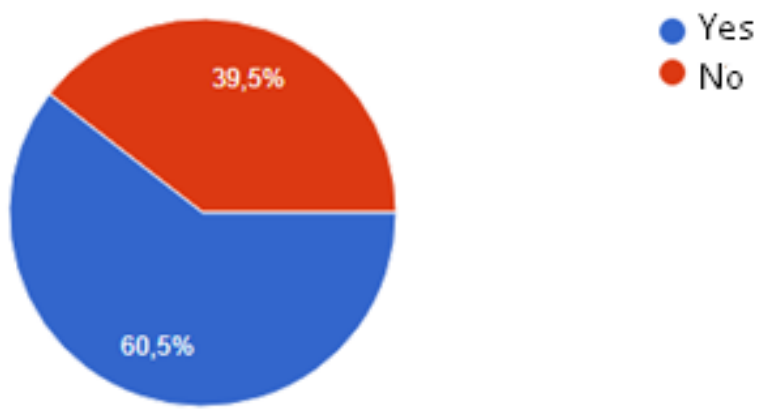

From this chart, we can conclude that most of the respondents are familiar with the technology of unmanned auto control. 
Question 3. Will you feel safe driving an unmanned vehicle?

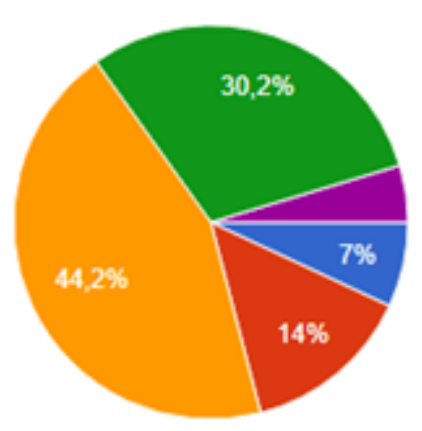

Absolutely unsafe

Insecure

Difficult to answer

Safely

Completely safe

Almost half of the respondents surveyed found it difficult to answer. About $30 \%$ would safely feel in an unmanned car.

Question 4. What most attracts you in an unmanned vehicle?

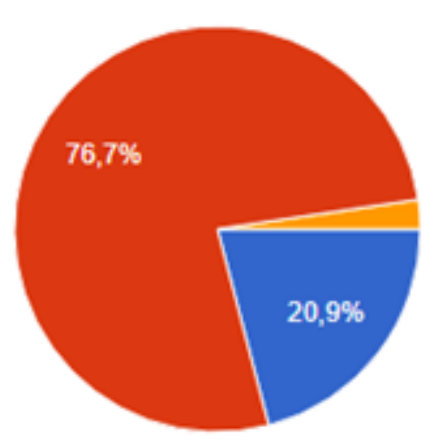

Security

The ability to do anything else

other

More than $70 \%$ are attracted by the opportunity to engage in driving an autonomous car with their own business.

Question 5. What scares you most in unmanned cars?

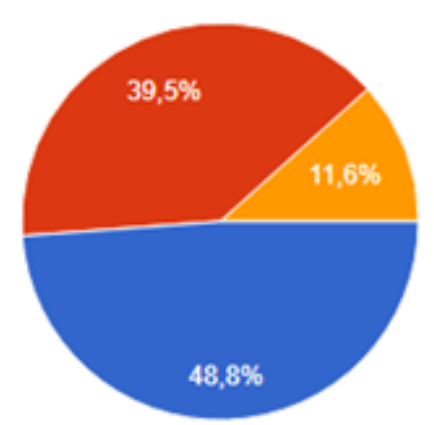

- Possibility of technical failure

- Inability to influence the situation

The ability to be hacked

About half of respondents fear the possibility of technical failure in work. 

do?

Question 6. If you had the chance to use an unmanned vehicle today, what would you

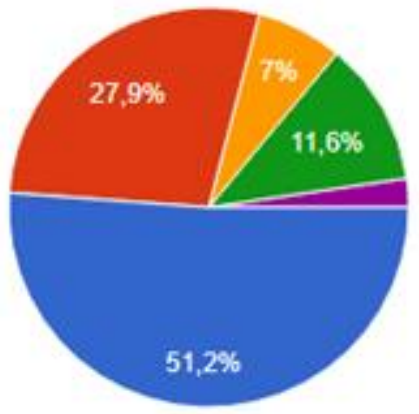

I certainly would.

More like Yes.

Difficult to answer

Rather not.

Definitely not.

Based on the diagram, we see that most of the respondents would like to try autonomous control.

Question 7. Do you think that autonomous cars will be useful to society?

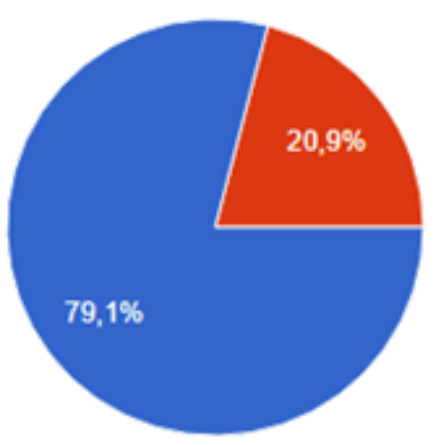

Yes

- No

It follows from this diagram that $79 \%$ of respondents consider unmanned cars useful.

Question 8. Do you think that with the advent of unmanned vehicles the number of accidents will decrease?
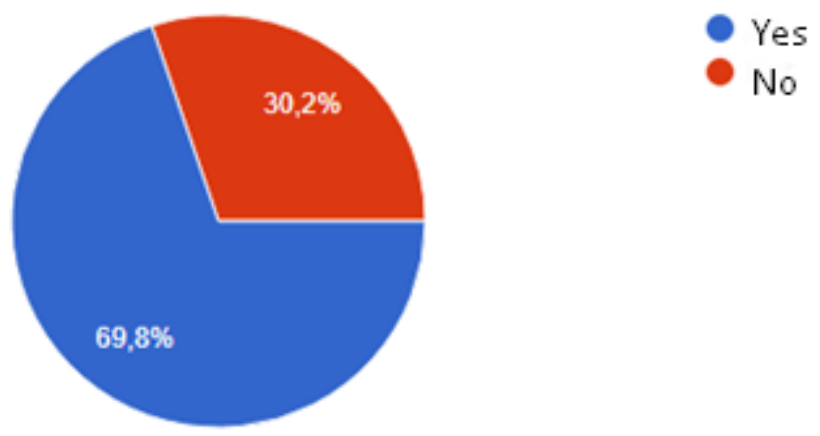

It can be seen that almost the same number of respondents believe that the number of accidents will decrease after the introduction of unmanned vehicles. Thus, hypothesis 1 is not 
confirmed - respondents do not believe that a car without driver participation will be more likely to get into accidents. module?

Question 9. Are you familiar with the Ukrainian development - Pilotdrive autopilot

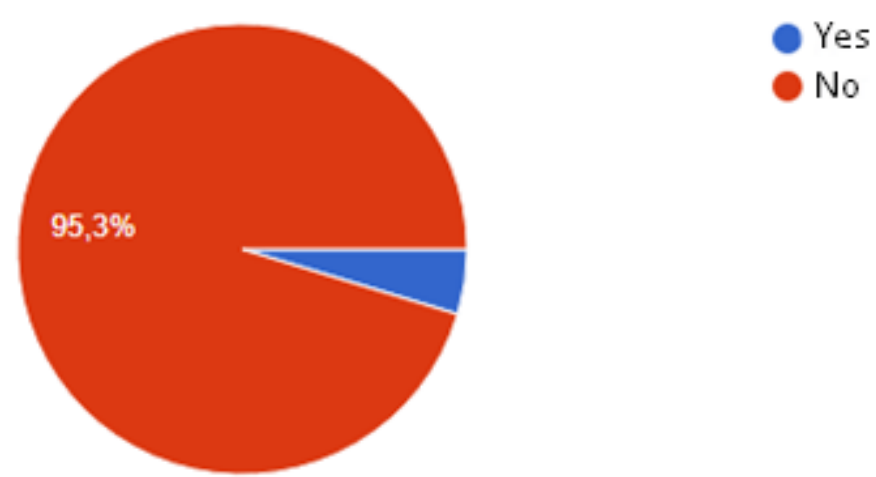

Only 2 respondents from 43 heard about the Ukrainian development.

Question 10. Do you believe that Ukraine can become one of the leaders in the world market for unmanned technology?
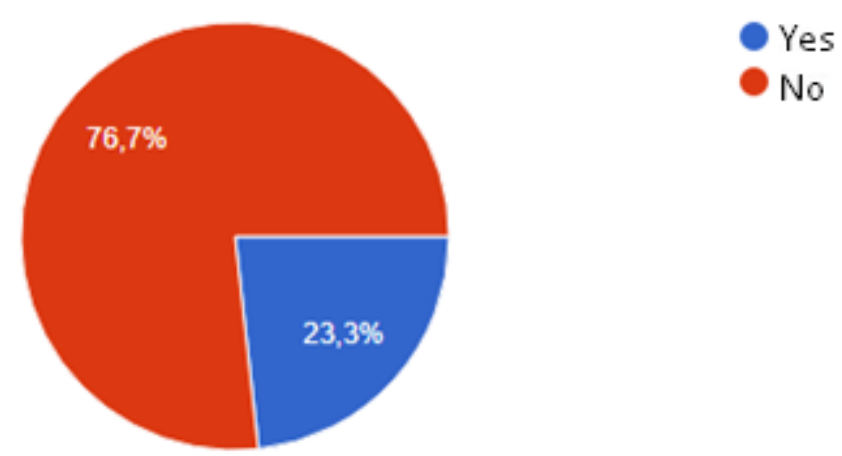

Less than $25 \%$ of respondents believe that Ukraine will be able to become the market leader in unmanned vehicles.

Question 11. The question was open, aimed at identifying the main problems hindering the development and implementation of unmanned vehicles in Ukraine.

In general, respondents identified the following problems:

- Low level of technical development.

- Low level of driving culture.

- Insufficiency of financing.

- The quality of roads (including the absence of normal marking).

- Political problems (corruption, bureaucracy). 
Question 12. Determination of the age structure of respondents.

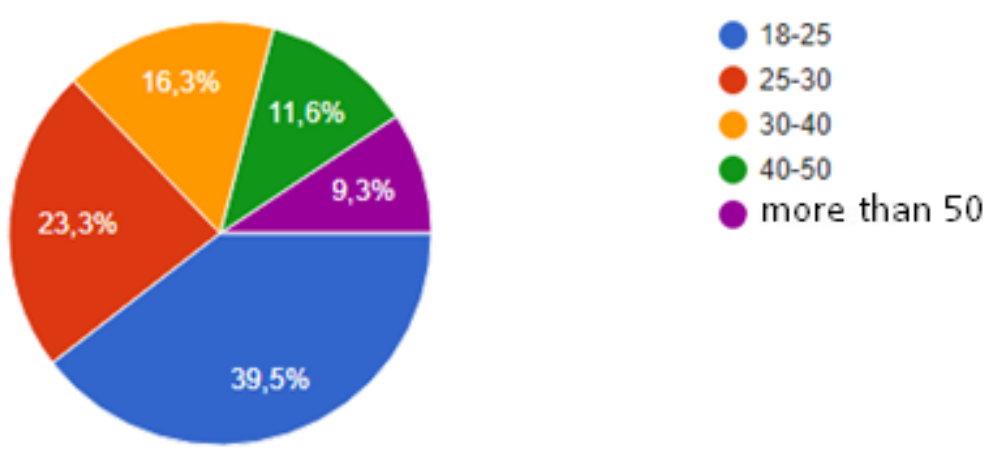

Most of the respondents were people aged 18 to 25 years.

Question 13. Determination of the gender structure of respondents.

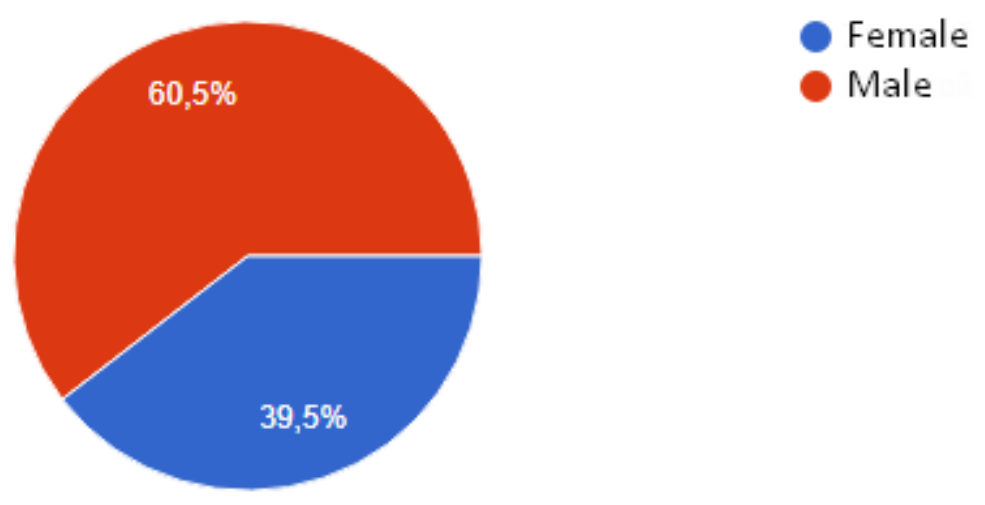

$60 \%$ of respondents are men.

The next step was to use the SPSS program to analyze the responses of respondents, and to identify the influence of factors.

Using the contingency table, we will try to establish a connection between the age and the attitude to the safety level of the technology (questions 3, 12)

Summary of processing of observations

\begin{tabular}{|c|c|c|c|c|c|c|}
\hline & \multicolumn{6}{|c|}{ Observations } \\
\hline & \multicolumn{2}{|c|}{ Valid } & \multicolumn{2}{|c|}{ Missing } & \multicolumn{2}{|c|}{ Total } \\
\hline & $N$ & $\%$ & $N$ & $\%$ & $N$ & $\%$ \\
\hline $\mathrm{Age}^{*}$ Driving safely & 43 & $100,0 \%$ & 0 & $0,0 \%$ & 43 & $100,0 \%$ \\
\hline
\end{tabular}




\section{Conjugacy table Age * Safely}

Частота

\begin{tabular}{|c|c|c|c|c|c|c|c|}
\hline & \multicolumn{5}{|c|}{ Safely } & \multirow[b]{2}{*}{ Total } \\
\hline & & Totally unsafe & unsafe & undecided & safe & Totally safe & \\
\hline \multirow[t]{5}{*}{ Age } & $18-25$ & 0 & 3 & 9 & 5 & 0 & 17 \\
\hline & $25-30$ & 2 & 2 & 2 & 3 & 1 & 10 \\
\hline & $30-40$ & 1 & 1 & 3 & 2 & 0 & 7 \\
\hline & $40-50$ & 0 & 0 & 3 & 2 & 0 & 5 \\
\hline & more than 50 & 0 & 0 & 3 & 0 & 1 & 4 \\
\hline Total & & 3 & 6 & 20 & 12 & 2 & 43 \\
\hline
\end{tabular}

From the contingency table, we see that respondents aged 18-25 consider unmanned vehicles safe.

Next, we need to find out whether the gender of the respondents affects the desire to use the technology. For this, the data obtained were entered into the SPSS program using univariate analysis of variance.

Summary of processing of observations

\begin{tabular}{|l|c|c|c|c|c|c|}
\hline \multirow{2}{*}{} & \multicolumn{9}{|c|}{ Observations } \\
\cline { 2 - 8 } & \multicolumn{2}{|c|}{ Valid } & \multicolumn{2}{c|}{ UnValid } & \multicolumn{2}{c|}{ Итого } \\
\cline { 2 - 8 } & $\mathrm{N}$ & $\%$ & $\mathrm{~N}$ & $\%$ & $\mathrm{~N}$ & $\%$ \\
\hline Gender * Chance to use & 43 & $100,0 \%$ & 0 & $0,0 \%$ & 43 & $100,0 \%$ \\
\hline
\end{tabular}

Contingency table Gender * the Chance to use

\begin{tabular}{|c|c|c|c|c|c|c|c|}
\hline & & \multicolumn{5}{|c|}{ Chance to use } & \multirow[b]{2}{*}{ Итого } \\
\hline & & $\begin{array}{c}\text { Absolutelly } \\
\text { yes }\end{array}$ & yes & Dont know & no & Absolutelly no & \\
\hline \multirow[t]{2}{*}{ Gender } & Yes & 7 & 7 & 2 & 2 & 0 & 18 \\
\hline & No & 16 & 5 & 0 & 3 & 1 & 25 \\
\hline \multicolumn{2}{|l|}{ Total } & 23 & 12 & 2 & 5 & 1 & 43 \\
\hline
\end{tabular}

It can be concluded that the gender of the respondents does not affect the attitude towards technology. The hypothesis is not confirmed.

Also, let us analyze whether familiarity with the technology affects the desire to use it with the help of the contingency table:

We see that the familiarity of the respondents with the technology does not affect the desire to use it.

Using the t-test analysis for independent samples, we will analyze whether the presence of a driver's license affects the opinion that with the introduction of drones, the number of accidents will decrease. 
Significance higher than 0.05 , which means people with driving license and experience do not believe that unmanned vehicles can affect the reduction of road accident on the roads.

The final cluster centers

\begin{tabular}{|l|c|c|}
\hline \multirow{2}{*}{} & \multicolumn{2}{|c|}{ Cluster } \\
\cline { 2 - 3 } & 1 & 2 \\
\hline Driving safely & 2.96 & 3.33 \\
Chance to take advantage & 1.86 & 1.67 \\
Age & 1.54 & 1.87 \\
Attracts in the car & 1.75 & 1.93 \\
Scary in a car & 1.42 & 3.87 \\
\hline
\end{tabular}

After that we build cluster analysis and dendrogram by the Ward method.

Based on the results obtained, the respondents can be divided into two clusters:

Skeptics are wary of drones, perhaps they believe that technologies are not fully understood and may be dangerous to humans. Not sure if they would use autonomous control in the near future. Most of all it scares the possibility of technical failures in work, it attracts the convenience and comfort in the car. People under the age of 30 years.

Enthusiasts - not afraid to try everything new, without hesitation would take advantage of autonomous cars. They are considered to be completely safe and useful to society. People over 30 years old.

We use factor analysis with the rotation of elements using the Varimaks method:

We can distinguish the following factors affecting the responses of respondents:

- The main safety in the car (high marks for questions 1.2 and low for 3.4).

- More attention to personal comfort (high scores for question 3, low at 1 and average for 2).

Conclusions from this research and prospects for further developments in this areaA huge ecosystem of dozens of companies of different types is forming around selfmanaged cars that will create a multi-billion dollar market for the already familiar movement in personal vehicles. Most foreign automakers and technology companies are working and field testing. Bulk self-driving cars may in some countries face serious legal barriers to regulators that can push back the spread of autonomous driving for up to 2-3 years after the technology is actually ready. In addition, the implementation will contain a number of technological, legal, informational and consumer risks. Ukrainian manufacturers are not yet able to compete with world leaders, at the moment there is only one Ukrainian development.

- In view of the insufficient level of development, the population does not yet have a sufficient level of confidence in innovation. There are doubts about the reliability of the technology.

- The consequence of the emergence of unmanned vehicles will be a huge change in society, akin to the fact that occurred with the advent of personal computers, the Internet, ubiquitous communications and smartphones. People will have a lot of extra time, reduce the level of stress, new career opportunities will appear, the demand for parking will significantly decrease, which will make room in cities for some other services. In the future, with people moving from driving to driving, cars will become the most important device generating mobile data. Autonomous machines and technologies of "smart cities" will gradually change 
entire industries, will give rise to the emergence of new industries. However, for all this to become real and affordable, it is necessary to carry out changes in the infrastructure of cities.

- Based on the answers to the open question of the questionnaire, for many, the car manufacturer matters. Respondents preferred the well-known foreign manufacturers, who have long been "heard". For Ukrainian developments are skeptical. The relationship between gender / age / driving experience and attitudes towards technology has not been identified.

- Only 2 respondents from the respondents knew about the presence of the Ukrainian development. This indicates a low level of public awareness about domestic research.

- In order to increase confidence in the technology of autonomous control, it is necessary, first of all, to raise the level of awareness of the population about the possibilities of innovation by developing various measures. Also, it is necessary to improve the attitude of the population to the Ukrainian developments.

Based on the open answers of the respondents, we can say that the greatest changes should occur in the organizational plan:

1. Creating a legislative framework.

2. Improving road infrastructure: replacing road signs and traffic lights with new ones, improving road quality and marking.

3. Increased funding and support from the state towards Ukrainian developers.

Also, the following hypotheses were confirmed during the study:

- users are most afraid of the inability to influence the situation.

- Respondents have an idea of the work of technology management without human intervention.

- confidence in the development of Ukrainian production at a low level.

- Denied:

- consumers believe that a car without driver participation will be more likely to get into accidents;

- The gender of the respondents affects attitudes towards drones.

- unmanned cars attract more people under 30;

- The older generation is not ready for the emergence of autonomous vehicles on the roads.

According to the results of cluster analysis, the respondents were divided into skeptics and enthusiasts. Also, 2 factors influencing the answers were highlighted: the main safety in cars, more attention to personal comfort.

1. Stewart, K., \& Williams, M. (2005). Researching online populations: the use of online focus groups for social research. Qualitative Research, 5,395-416.

2. James, N., \& Busher, H. (2006). Credibility, authenticity and voice: dilemmas in online interviewing. Qualitative Research, 6.

3. Global Market Research 2016. (2016). An ESOMAR Industry Report in cooperation with BDO Accountant \& Advisiors. Publisher by ESOMAR, Amsterdam, The Netherlands, 158.

4. Official Website SAE Internation. www.sae.org Retrieved from: https://www.sae.org.

5. Official Website 2035.media. www.2035.media Retrieved from: http://2035.media/2017/04/06/ mediadigest-cars.

6. Official Website Kommersant. www.kommersant.ru Retrieved from: https://www.kommersant. $\mathrm{ru} / \mathrm{doc} / 3213682$.

7. Official Website RGRU. www.rg.ru Retrieved from: https://rg.ru/2016/09/21/kak-bespilotnyeavtomobili-budut-reshat-voprosy-zhizni-i-smerti.html.

8. Official Website Autocentre. www.autocentre.ua Retrieved from: https://www.autocentre. ua/avtopravo/dorogi/bespilotnie-avto-chto-budet-esli-oni-poyavyatsya-v-ukraine-314466.html. 
9. Official Website JSONTV. www.json.tv Retrieved from: http://json.tv/ict_telecom_analytics_ view/mirovoy-rynok-samoupravlyaemyh-avtomobiley-v-2020-2035-godah-20170828042106.

10. Oklander, M.A. (2013). Suchasni transformatsii kulturnykh chynnykiv povedinky spozhyvacha [Modern transformations of cultural factors of consumer behavior]. Ekonomichnyi visnyk Natsionalnoho tekhnichnoho universytetu Ukrainy "Kyivskyi politekhnichnyi instytut" - Economic Herald of the National Technical University of Ukraine "Kyiv Polytechnic Institute", 10, 386-392 [in Ukrainian].

Радкевич Л.А., канд. екон. наук, дочент, доиент кафедри маркетингу, Одеський національний політехнічний університет (Одеса, Україна).

Дубович Г.С., магістр маркетингу кафедри маркетингу Одеського національного політехнічного університету (Одеса, Украӥна).

\section{Маркетингові дослідження перспектив розвитку беспілотних транспортних} автомобілів в Україні.

Стаття присвячена особливостям впровадження безпілотного транспорту в Україні. Розглянуто проблеми, які виникають в процесі освоєння інновації. Шляхом анкетування було виявлено ставлення споживачів до появи безпілотних автомобілів. На основі проведеного дослідження сформовано рекомендаиіï, для ефективного впровадження безпілотного транспорту.

Ключові слова: маркетингове дослідження, безпілотний транспорт, інноваційний транспорт. 